\title{
Natural enrichments of $\mathrm{Cd}$ and $\mathrm{Tl}$ in bark of trees consumed by beaver (Castor canadensis) in a rural watershed devoid of point sources of metal contamination
}

FIORELLA BARRAZA, WILLIAM SHOTYK, CHAD W. CUSS, IAIN GRANT-WEAVER, MUHAMMAD B. JAVED, CARLA GERMANI AND TOMMY NOERNBERG

University of Alberta

Presenting Author: barrazac@ualberta.ca

In a previous study of beaver (Castor canadensis) from a small stream in a rural region of southern Ontario, organ tissue, especially kidney, had remarkable enrichments of $\mathrm{Cd}$ and $\mathrm{Tl}$ $(13.3 \pm 4.8 \mathrm{mg} / \mathrm{kg}$ and $68 \pm 61 \mu \mathrm{g} / \mathrm{kg}$ respectively, $\mathrm{n}=5)$. However, the concentration of both elements in the dissolved fraction $(<0.45 \mu \mathrm{m})$ of the river is very low: $1.2 \pm 0.3$ and $1.6 \pm$ $0.1 \mathrm{ng} / \mathrm{l}$ of $\mathrm{Cd}$ and $\mathrm{Tl}$ respectively (Shotyk et al., 2019: https://doi.org/10.1016/j.scitotenv.2019.03.303).

To help explain this phenomenon and determine whether the accumulation of $\mathrm{Cd}$ and $\mathrm{Tl}$ in beaver tissue can be attributed to the diet of the animal, bark was collected from 40 species of trees and shrubs from the same location as well as soil and sediments. All the samples were analyzed in the metal-free, ultraclean SWAMP lab (www.swamp.ualberta.ca) following an acid digestion procedure and ICP-MS analysis.

Willow and poplar, two favourite foods of the beaver, are very rich in $\mathrm{Cd}$ (up to $8.5 \mathrm{mg} / \mathrm{kg}$ ) whereas soils and underlying lacustrine sediments from which the soils were derived show $\mathrm{Cd}$ concentrations ranging from 77 to $394 \mu \mathrm{g} / \mathrm{kg}$.

The values recorded for the transfer factor (TF), using the 1.5 $m$ depth soil layer to calculate the enrichment of $\mathrm{Cd}$ in bark, in willow and poplar vary between 5 and 21. Even though $\mathrm{Cd}$ is potentially toxic, these plants preferentially accumulate this metal over essential micronutrients such as $\mathrm{Cu}, \mathrm{Mn}, \mathrm{Ni}$ and $\mathrm{Zn}$. At the same time normalizing the $\mathrm{Cd} /$ metal ratios in bark to the corresponding ratios in the dissolved fraction of the river yields the Stream Enrichment Factor: this shows that all plant species accumulate $\mathrm{Tl}$ preferentially over $\mathrm{Rb}$; in this case, neither is essential, but the former is more toxic than the latter.

Our results suggest that the abundance of $\mathrm{Cd}$ versus $\mathrm{Tl}$ in plant and beaver tissue is not a reflection of differences in bioavailability, but rather on the preferential uptake of $\mathrm{Cd}$ by plants. Apparently, the biogeochemical cycle of $\mathrm{Cd}$ in the riparian zone is dominated by active plant uptake, and this has ramifications for biomonitoring of environmental contamination. 